J. Asiat. Soc. Bangladesh, Sci. 38(2): 247-255, December 2012

\title{
DIALLEL CROSS ANALYSIS OF FILAMENT LENGTH IN THE SILKWORM, BOMBYX MORI L.
}

\author{
H. A. RASHID ${ }^{1}$, S. M. RAHMAN AND M. K. AHSAN* \\ Department of Zoology, Rajshahi University, Rajshahi-6205, Bangladesh
}

\begin{abstract}
A diallel analysis for filament length in six varieties of silkworm, Bombyx mori $\mathrm{L}$. having a wide range of variability has been genetically analysed by means of $6 \times 6$ diallel cross. The results indicated that both additive and non-additive genetic variations were important for determining the expression of this trait. Besides the dominance, deviation of genes present in this diallel existed predominantly in one direction and they were independent of reciprocal effect and some of the parents contained more dominant than recessive alleles in S-1 and S-3. The presence of specific dominance effect which were peculiar to individual crosses and a significant part of it was independent of reciprocal effect. The regression of filament length is deviated significantly from unity in majority of the seasons (except S-4) giving a contrasting result implying the presence of nonallelic interaction. The distribution of genes for two seasons (S-2 and S-3) was not symmetrical, while the rest two seasons (S-1 and S-4) showed symmetrical distribution of positive and negative among the parents. In narrow sense heritability was found to be medium to high and the broad sense heritability was high among the studied varieties.
\end{abstract}

Key words: Diallel cross, Filament length, B. mori L.

\section{Introduction}

The diallel cross method of assessing potential breeding material, which has been used for some forty years in plant breeding, has found no comparable place in animal breeding. Yet the advantages of this breeding programme apply equally to both plant and animal material especially now that much of animal breeding is directed towards the increasing of productivity. Review of literatures revealed that the rank of $B$. mori is the second in genetic studies next to Drosophila. Most of the economic characters are, however, quantitative in nature and a knowledge of the mode of inheritance of quantitative characters is a prerequisite to accomplish an effective and meaningful breeding programme in crops (Bhadra and Dey 1985 and Shamsuddin and Antoun 1986) and animals (Reza and Rahman 2005, Zhao et al. 2007 and Ahsan and Rahman 2008) for their improvement.

Diallel cross study has been used to evaluate the potential of parents and crosses in the $F_{1}$ generation and for analyzing inheritance patterns of genes regulating quantitative characters in silkworm by Krishnaswami et al. (1964), Gamo and Hirabayashi (1983),

* Corresponding author: Lecturer, Government Rajendra College, Faridpur. 
Jeong et al. (1986), Satenahalli et al. (1989), Sarker et al. (1991), Rahman and Jahan (2001) and Rahman et al. (2004). However, very little information is available on the nature of gene actions and their interactions influencing different economic traits of introduced and indigenous varieties of silkworm in Bangladesh. Studies were, therefore, initiated with a $6 \times 6$ complete diallel set of indigenous and introduced varieties of the silkworm, B. mori L. of Bangladesh to characterize the genetic architecture of filament length, which would facilitate the choice of desirable parents and the formulation of an effective breeding programme.

\section{Materials and Methods}

The present experiments conducted with six varieties of silkworm, Bombyx mori L. which include five multivotine: Nistari, Nistari oval (G), BSRI-95, Nan Nung-7B, BSRI-98 and one bivoltine variety: $\mathrm{BV}$ (High) and its $30 \mathrm{~F}_{1} \mathrm{~s}$ obtained by crossing the parents in diallel fashion including reciprocals. The experiment was conducted in four rearing seasons corresponding to commercial rearing seasons as practiced by farmers in Bangladesh. These rearing Bensalic seasons were Agrahyon (October-November), Chaitra (FebruaryMarch), Jaistha (May-June) and Bhadra (August). For each genotype three diseases free Layn CDFLs were brushed in three separate rearing trays $(45 \times 30 \times 6 \mathrm{~cm})$ in a randomized design with three replications. Each rearing tray was considered as a replication in this investigation. Rearing of silkworm larvae was conducted following the scientific technology of Krishnaswami (1978) and Rahman (1983).

Data collected on filament length in metres were analyzed following the diallel techniques of analysis as developed by Jinks and Hayman (1953), Hayman (1954), Dickinson and Jinks (1956) and Johnson and Aksel (1964). Results are interpreted mainly in two approaches. Equations are derived and solved to obtain estimates of the genetic parameters $\mathrm{D}, \mathrm{h}_{1}, \mathrm{~h}_{2}, \mathrm{~h}^{2}$ and $\mathrm{F}$ which are interpretable on the basis of diallel theory of Hayman (1954). Alternatively, results in terms of genetical control of the characters are interpreted by constructing statistical graphs.

\section{Results and Discussion}

Results on Hayman's analysis of variance of diallel table for filament length have been presented in Table 1. The main effects ' $a$ ' and ' $b$ ' were found to be significant against all the three test of significance for all the four rearing seasons indicating that both additive and non-additive genetic variations were important for determining the expression of this trait. The present analysis was substantiated by the findings of Gamo et al. (1985), Hirabayashi and Gamo (1985), Jeong et al. (1986), Rahman and Jahan, (2001) and Rahman et al. 2004 in the mulberry silkworm. Rahman (1984) reported that both additive and dominance components of genetic variations were important in the inheritance of larval, pupal and cocoon characters in the eri silkworm, Philosamia ricini. 
The item ' $b_{1}$ ' exhibited significant $\mathrm{VR}_{1}, \mathrm{VR}_{2}$ and $\mathrm{VR}_{3}$ in all the four rearing seasons. The results suggested that the dominance deviation of genes presents in this diallel existed predominantly in one direction and they were independent of reciprocal effect. The ' $b_{2}$ ' item showed significant result against only pooled error in S-2, pooled error and ' $d$ ' in S-1 and S-3 while insignificant result in S-4. The results indicated that some of the parents contained more dominant than recessive alleles in S-1 and S-3. On the other hand, distributions of genes were symmetrical in $S-4$. The item ' $b_{3}$ ' showed significant $\mathrm{VR}_{1}$, $\mathrm{VR}_{2}$ and $\mathrm{VR}_{3}$ in all the rearing seasons implying the presence of specific dominance effect which were peculiar to individual crosses and a significant part of it was independent of reciprocal effect.

No reciprocal differences of any kind either 'c' or ' $d$ ' was found to be significant except in S-3 for the item 'c' $\left(\mathrm{VR}_{2}\right)$. Rahman (1994) also reported that there was no reciprocal difference for filament length in the diallel cross of the silkworm, B. mori. But reciprocal difference for cocoon size presence in the secific crosses of the silkworm, B. mori was reported by Rahman and Jahan (2001).

The $\mathrm{Wr}, \mathrm{Vr}$ graph for filament length for all the seasons are shown in Fig. 1. The regression coefficients (b) were $0.716 \pm 0.053,0.670 \pm 0.152,0.409 \pm 0.181$ and $0.867 \pm 0.205$ for the seasons S-1, S-2, S-3 and S-4 respectively.

Table 1. Hayman's analysis of variance of diallel table for filament length of B. mori L. in different rearing seasons.

\begin{tabular}{|c|c|c|c|c|c|}
\hline \multirow{2}{*}{ Item } & \multirow{2}{*}{ d. f. } & \multicolumn{4}{|c|}{ Mean sum of squares } \\
\hline & & S-1 & S-2 & S-3 & S-4 \\
\hline $\mathrm{a}$ & 5 & $65139.21^{* \#+}$ & $66198.26^{* \# \dagger}$ & $34592.41^{* \#+}$ & $10961.52^{* \#+}$ \\
\hline b & 15 & $6569.60^{\text {*\#t }}$ & $6238.31^{\text {*\# }}$ & $6758.06^{* \#+}$ & $6624.16^{* \#+}$ \\
\hline $\mathrm{b}_{1}$ & 1 & $43464.49^{* \#+}$ & $28164.21^{\text {*\#† }}$ & $38874.71^{\text {*\#† }}$ & $35129.85^{* \# \dagger}$ \\
\hline $\mathrm{b}_{2}$ & 5 & $2723.11_{*+}^{* \dagger}$ & $3446.91^{\text {*\#+ }}$ & $4597.05^{*+}$ & 1080.51 \\
\hline $\mathrm{b}_{3}$ & 9 & $4607.11^{\text {*\#t }}$ & $5352.87^{* \#+}$ & $4390.10^{* \#+}$ & $6536.66^{* \#+}$ \\
\hline $\mathrm{c}$ & 5 & 182.29 & 545.92 & $599.74^{\dagger}$ & 1473.49 \\
\hline d & 10 & 156.55 & 507.21 & 170.08 & 1234.97 \\
\hline $\operatorname{Rep}(\mathrm{R})$ & 2 & 3.95 & 0.68 & 0.82 & 0.05 \\
\hline $\mathrm{R} \times \mathrm{a}$ & 10 & 788.75 & 697.47 & 332.10 & 780.79 \\
\hline $\mathrm{R} \times \mathrm{b}$ & 30 & 1222.74 & 701.01 & 1215.63 & 680.39 \\
\hline $\mathrm{R} \times \mathrm{b}_{1}$ & 2 & 2250.85 & 712.04 & 1166.39 & 173.48 \\
\hline $\mathrm{R} \times \mathrm{b}_{2}$ & 10 & 948.34 & 950.52 & 1470.18 & 1181.52 \\
\hline $\mathrm{R} \times \mathrm{b}_{3}$ & 18 & 1260.96 & 561.17 & 1079.68 & 458.29 \\
\hline $\mathrm{R} \times \mathrm{c}$ & 10 & 1307.59 & 973.45 & 759.65 & 1275.15 \\
\hline $\mathrm{R} \times \mathrm{d}$ & 20 & 633.91 & 1327.36 & 766.09 & 1124.68 \\
\hline $\begin{array}{l}\text { Pooled } \\
\text { error }\end{array}$ & 70 & 1004.63 & 918.38 & 895.83 & 906.64 \\
\hline
\end{tabular}

*\# and ${ }^{\dagger}$ significant at least at $5 \%$ level; tested against pooled error $\left(\mathrm{VR}_{1}\right)$, interaction with own block $\left(\mathrm{VR}_{2}\right)$ and with the item 'd' $\left(\mathrm{VR}_{3}\right)$ respectively. 


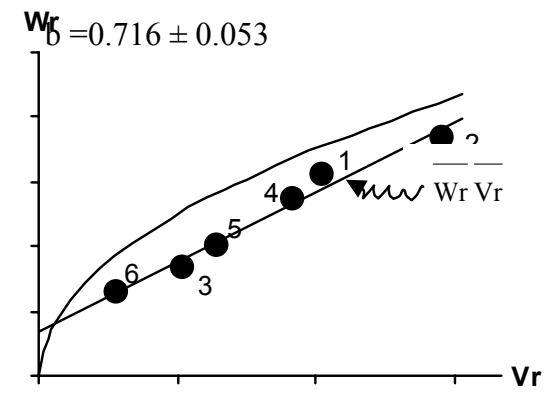

S-1

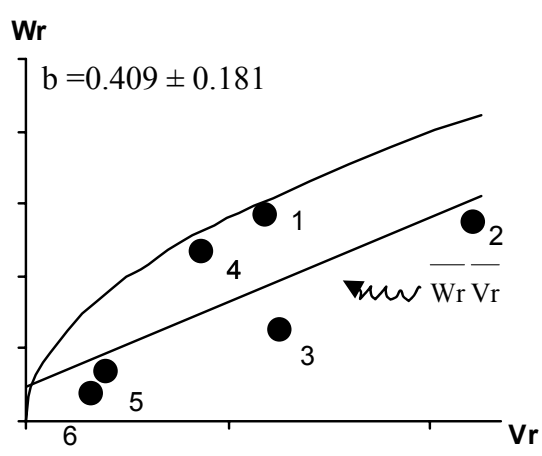

S-3

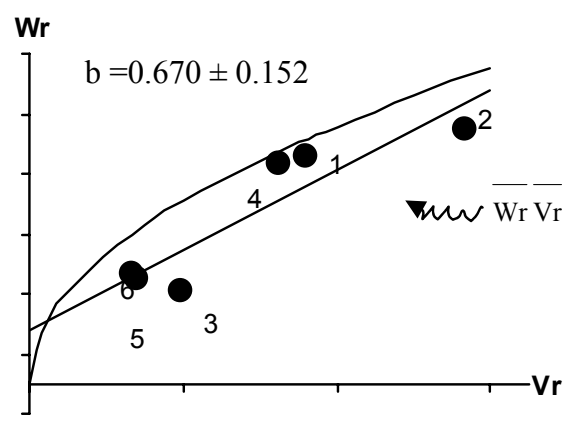

S-2

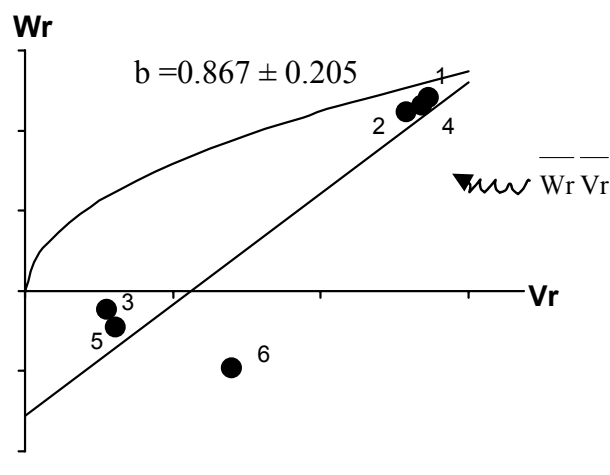

S-4

Fig.1. The $\mathrm{Wr} / \mathrm{Vr}$ graph for filament length of B. mori L . in different rearing seasons. $\mathrm{Wr}=$ Parentoffspring co-variances, $\mathrm{Vr}=$ Array variances; $1=$ Nistari, $2=$ Nistari oval $(\mathrm{G}), 3=$ BSRI-95, $4=$ NanNung7B, $5=$ BSRI-98, $6=$ BV(high); S-1: Agrahyon (October-November) rearing season, S-2: Chaitra (February-March) rearing season, S-3: Jaistha (May-June) rearing season, S-4: Bhadra (August) rearing season.

The regression of $\mathrm{Wr}, \mathrm{Vr}$ was significant for all the seasons and they do not deviate significantly from 0 (zero) except S-3 and S-4 indicating the absence of non-allelic interaction. However, the regression is deviated significantly from unity in majority of the seasons (except S-4) giving a contrasting result implying the presence of non-allelic interaction. Rahman (1994) also reported the absence of non-allelic interaction for filament length in B. mori.

The regression lines cut the Wr axis above the point of origin in S-1, S-2 and S-3 suggesting an overall partial dominance. While the season S-4 showed an average over dominance as its line cuts below the point of origin. The array points in all the rearing seasons lied very close to the regression line which is also an indication of the absence of 
non-allelic interaction in these diallels. The recurrent parents of arrays 2 (S-1. S-2 and S3 ); and 1, 2 and 4 (S-4) were furthest away from the point of origin bearing an excess of recessive genes and were responsible for poor filament length in B. mori. The arrays 6 (S1); 5 and 6 (S-2 and S-3) and 3 and 5 (S-4) were located almost near the point of origin of the regression line and hence possessed excess of dominant genes. Array points 1, 3, 4 and 5 (S-1); 1, 4 (S-2); 1, 3 and 4 (S-3) and 6 (S-4) occupying an intermediate position along the regression line, possessed more or less equal proportion of dominant and recessive genes (Fig. 1). In the variance analysis of $\mathrm{Wr}+\mathrm{Vr}$ (Table 2), significant $\mathrm{Wr}+\mathrm{Vr}$ item for all the seasons indicated that significant dominant and recessive relationship does exist among the parents for this character.

Table 2. Analysis of variance of $(\mathrm{Wr}-\mathrm{Vr})$ and $(\mathrm{Wr}+\mathrm{Vr})$ values of six parent diallel for filament length in B. mori $\mathrm{L}$.

\begin{tabular}{lccccc}
\hline \multirow{2}{*}{ Item } & d. f. & \multicolumn{5}{c}{ Mean sum of squares } \\
\cline { 3 - 6 } & & \multicolumn{1}{c}{$\mathrm{S}-1$} & \multicolumn{1}{c}{ S-2 } & \multicolumn{1}{c}{ S-3 } & S-4 \\
\hline Rep. & 2 & $6163060.18^{* *}$ & $2272628.61^{*}$ & $6443880.19^{* *}$ & 72816.21 \\
Wr - Vr & 5 & 313244.43 & $1615534.07^{*}$ & $3326544.04^{* *}$ & 547065.85 \\
Error & 10 & 272675.26 & 404696.63 & 525453.16 & 268752.81 \\
\hline Rep. & 2 & 4035696.34 & 2214455.27 & 1226832.91 & 310793.32 \\
Wr $+\mathrm{Vr}$ & 5 & $19917112.48^{*}$ & $23380315.91^{* *}$ & $12503795.67^{* *}$ & $7386302.02^{* *}$ \\
Error & 10 & 3836707.52 & 1850183.88 & 859010.04 & 1260410.03 \\
\hline
\end{tabular}

$* \mathrm{P}<0.05$ and $* * \mathrm{P}<0.01, \mathrm{~S}-1$ : Agrahyon (October-November) rearing season, S-2: Chaitra (February-March) rearing season, S-3: Jaistha (May-June) rearing season, S-4: Bhadra (August) rearing season.

The standardized deviation graph with $\hat{\mathrm{Y}} \mathrm{r}$ and $\hat{\mathrm{W}} \mathrm{r}+\hat{\mathrm{Vr}}$ was drawn and are presented in Fig. 2. Array points in the graph showed that dominance in the arrays 3, 5 and 6 (S-1, S-2 and S-4); and 5 and 6 (S-3) were due to an excess of positive genes. Arrays 1, 2 and 4 for S-1, S-2 and S-4; and 1 and 2 for S-3 possessed recessive genes and were of negative type. However, the array 4 in S-3 possessed more or less equal proportion dominant and recessive genes of negative nature. 


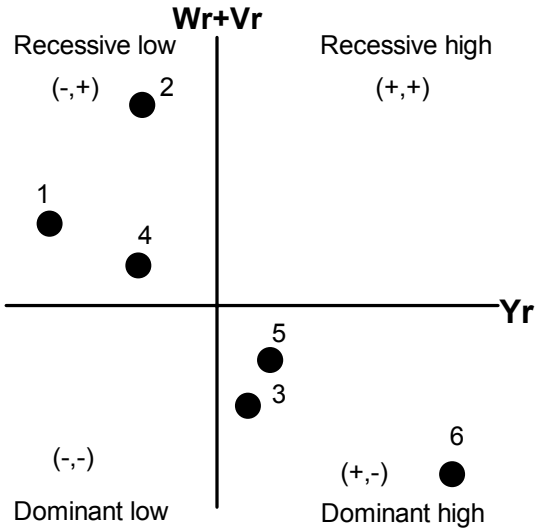

S-1

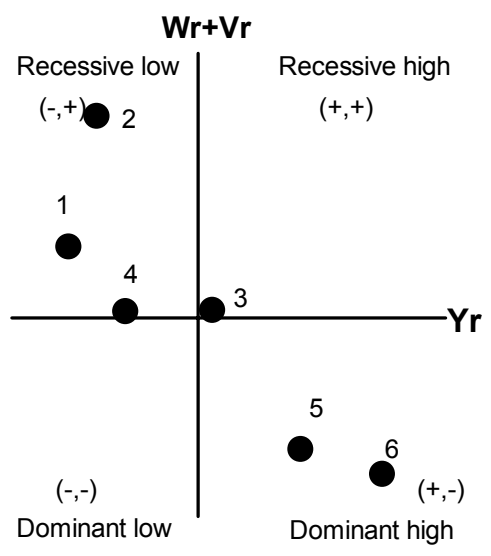

S-3

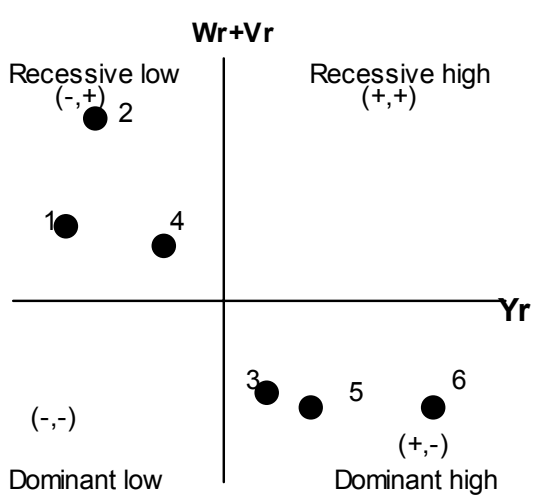

S-2

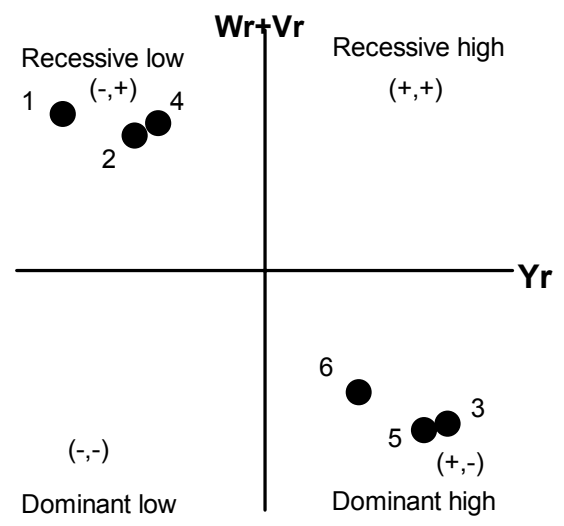

S-4

Fig. 2. The standardized deviation graph for filament length of B. mori $L$. in different rearing seasons. $1=$ Nistari, $2=$ Nistari oval $(G), 3=$ BSRI-95, $4=$ NanNung7B, $5=$ BSRI-98, 6 $=\mathrm{BV}$ (high); S-1: Agrahyon (October-November) rearing season, S-2: Chaitra (FebruaryMarch) rearing season, S-3: Jaistha (May-June) rearing season, S-4: Bhadra (August) rearing season.

The ( $\mathrm{D}$ ) component which measures additive effect was significant for majority of the seasons except S-4 indicating importance of additive in this character. The dominance component was also significant for all the seasons. The significant of $\left(\mathrm{H}_{2}\right)$ in all the four seasons indicated the dominance asymmetry for the inheritance of the trait. The degree of dominance was found to be partial in nature for the seasons S-1 and S-2 since the values 
of $\left(\hat{H}_{1} / \hat{D}\right)^{1 / 2}$ were less than one. But in the rest of the seasons the values were greater than unity suggesting over dominance. Similar observations were noted by the positive and negative values of $1 / 4\left(\mathrm{D}-\mathrm{H}_{1}\right)$ for those seasons respectively. Krisnaswami et al. (1964) in a six-parent diallel in the mulberry silkworm, B. mori L. noticed that over dominance and or epistatic interaction played a significant role in the genetic control of some characters.

Table 3. Components of variation and their ratios obtained from six parent diallel analysis for filament length in B. mori $\mathrm{L}$.

\begin{tabular}{|c|c|c|c|c|}
\hline \multirow{2}{*}{$\begin{array}{l}\text { Components \& } \\
\text { Ratios }\end{array}$} & \multicolumn{4}{|c|}{ Estimated values with standard error in different seasons } \\
\hline & S-1 & $\mathrm{S}-2$ & S-3 & S-4 \\
\hline$\hat{\mathrm{E}}$ & $\begin{array}{c}325.61 \\
\pm 131.76\end{array}$ & $\begin{array}{c}297.63 \\
\pm 215.86\end{array}$ & $\begin{array}{c}290 . \\
\pm 277.04\end{array}$ & $\begin{array}{c}293.82 \\
\pm 103.16\end{array}$ \\
\hline $\mathrm{D}$ & $\begin{array}{l}4620.15 \\
\pm 348.29\end{array}$ & $\begin{array}{l}4304.04 \\
\pm 570.63\end{array}$ & $\begin{array}{l}1641.82 \\
\pm 732.35\end{array}$ & $\begin{array}{c}487.27 \\
\pm 272.71\end{array}$ \\
\hline $\mathrm{F}$ & $\begin{array}{l}-2120.95 \\
\pm 846.98\end{array}$ & $\begin{array}{l}-2384.55 \\
\pm 1387.62\end{array}$ & $\begin{array}{l}-1276.99 \\
\pm 1780.89\end{array}$ & $\begin{array}{l}-588.50 \\
\pm 663.18\end{array}$ \\
\hline $\mathrm{H}_{1}$ & $\begin{array}{l}4116.57 \\
\pm 883.15\end{array}$ & $\begin{array}{c}4131.17 \\
\pm 1446.88\end{array}$ & $\begin{array}{c}4752.75 \\
\pm 1856.95\end{array}$ & $\begin{array}{l}3872.71 \\
\pm 691.49\end{array}$ \\
\hline $\mathrm{H}_{2}$ & $\begin{array}{l}3728.51 \\
\pm 789.76\end{array}$ & $\begin{array}{c}3563.61 \\
\pm 1293.87\end{array}$ & $\begin{array}{c}3924.73 \\
\pm 1660.57\end{array}$ & $\begin{array}{l}3828.47 \\
\pm 618.37\end{array}$ \\
\hline$\hat{\mathrm{h}}^{2}$ & $\begin{array}{l}7868.09 \\
\pm 527.33\end{array}$ & $\begin{array}{l}5050.24 \\
\pm 863.93\end{array}$ & $\begin{array}{c}7037.73 \\
\pm 1108.78\end{array}$ & $\begin{array}{l}6342.29 \\
\pm 412.89\end{array}$ \\
\hline$\hat{\mathrm{h}}^{2} / \hat{\mathrm{H}}_{2}$ & 2.11 & 1.42 & 1.79 & 1.66 \\
\hline$\sqrt{\hat{\mathrm{H}}_{1}} / \hat{\mathrm{D}}$ & 0.94 & 0.98 & 1.70 & 2.82 \\
\hline${ }^{1 / 4}\left(\hat{D}-\hat{H}_{1}\right)$ & 125.89 & 43.22 & -777.73 & -846.36 \\
\hline$\underset{1 / 2}{\hat{H}_{2} / 4 \mathrm{H}_{1}}$ & 0.23 & 0.22 & 0.21 & 0.25 \\
\hline$\hat{\mathrm{F}} / \sqrt{\hat{\mathrm{D}}\left(\hat{\mathrm{H}}_{1}-\hat{\mathrm{H}}_{2}\right)}$ & -0.79 & -0.76 & -0.55 & -2.00 \\
\hline $\begin{array}{l}\text { Heritability } \\
\text { (Narrow sense) }\end{array}$ & 0.5344 & 0.5113 & 0.3193 & -0.2332 \\
\hline $\begin{array}{l}\text { Heritability } \\
\text { (Broad sense) }\end{array}$ & 0.8795 & 0.8776 & 0.8446 & 0.7596 \\
\hline
\end{tabular}


The distribution of genes for two seasons (S-2 and S-3) was not symmetrical at loci showing dominance as their value of the fraction $\hat{\mathrm{H}}_{2} / 4 \hat{\mathrm{H}}_{1}$ was close to the expected value 0.25 . While in the rest two seasons (S-1 and $\mathrm{S}-4)$ the value of this estimate was close to the expected value suggesting symmetrical distribution of positive and negative among the parents. The values of ratio $1 / 2 \hat{F} / \sqrt{\hat{D}\left(\hat{H}_{1}-\hat{H}_{2}\right)}$ for all the seasons indicated the presence of excess of recessive alleles in the parents. Heritability values in narrow and broad sense were also calculated for all the seasons and are shown in Table 3. Narrow sense heritability was medium to high and the broad sense heritability was high. As to the practical implication of this study, it is suggested that the improvement in filament length may be achieved through simultaneous utilization of both additive and dominance variation by selection processes in further generations.

The results of the present investigation indicated that the inclusion of different generations over rearing seasons in a diallel cross is essential to draw reliable and worthwhile conclusion and that hybrid populations may behave differently under varied environmental conditions. Environmental effects on gene actions had been reported by Allard (1956a, b) where he had observed change in dominant effect depending upon the presence or absence of epistasis due to environmental changes (Sengupta et al. 1974).

$\hat{\mathrm{E}}=$ Environmental variance, $\hat{\mathrm{D}}=$ Additive variance, $\hat{\mathrm{F}}=$ Mean 'Fr' over the arrays, $\hat{\mathrm{H}}_{1}=$ Dominance variance, $\hat{\mathrm{H}}_{2}=$ Estimate for proportion of positive and negative genes, $\wedge^{2}$

$\hat{\mathrm{h}}=$ Dominance effect (Sum over all loci in heterozygous phase), S-1: Agrahyon (October-November) rearing season, S-2: Chaitra (February-March) rearing season, S-3: Jaistha (May-June) rearing season, S-4: Bhadra (August) rearing season.

\section{References}

Ahsan, M.K. and S.M. Rahman. 2008. Genetic variability and correlation analysis in hybrids of mulberry silkworm, Bombyx mori L. for egg characters. Univ j. zool. Rajshahi Univ. 27: 13-16.

Allard, R.W. 1956a. The analysis of genetic environmental interactions by means of diallel crosses. Genetics. 41: 305-319.

Allard, R.W. 1956b. Estimation of potency from lima bean diallel crosses. Agron. J. 48: 537-543.

Bhadra, S.K. and A. Dey. 1985. Genetic analysis of some yield contributing characters in mungbean, Vigna radiata. Bangladesh J. Agri. 10(1): 1-8.

Dickinson, A.G. and J.L. Jinks. 1956. A general analysis of diallel crosses. Genetics. 41: 65-78.

Gamo, T. and T. Hirabayashi. 1983. Genetic analysis of growth rate, population rate and some quantitative characters by diallel cross in the silkworm, Bombyx mori L. Jap. J. Breed. 33: $178-90$.

Gamo, T., Y. Otsuka, T. Fujishima, T. Hirobe and Y. Tazima 1985. Estimation of combining ability and genetic analysis by diallel crosses between regional races of silkworm (1) Rearing performances and cocoon yields. Tech. Bull. Seri. Expt. Sta. 126: 93-120.

Hayman, B.I. 1954. The analysis of variance of diallel crosses. Genetics. 39: 789-809. 
Hirabayashi, T. and T. Gamo. 1985. Study on the combining ability of Japanese and Chinese silkworm races with different voltinism by dialleld cross III. Shape and size of cocoons and their genetic analysis. Tech. Bull. Seri. Expt. Sta. 125: 91-104.

Jeong, W.B., K.Y. Chang, K.S. Han, J.H. Kim, K.D. Ryu, H.Y. Dhung and S.C. Ryu. 1986. Genetic analysis by diallel crosses in $\mathrm{F}_{1}$ generation of silkworm, B. mori L. Korean J. Seric. Sci. 28(1): $24-29$.

Jinks, J.L. and B.I. Hayman. 1953. The analysis of diallel crosses. Maize Genetics . News Letter. 27: 48-54.

Johnson, L.P.V. and R. Aksel. 1964. The inheritance of malting quality and agronomic characters in a diallel cross of barley. Can. J. Genet. Cytol. 6: 178-200.

Krishnaswami, S. 1978. New technology of silkworm rearing. Central Silk Board, Bombay, India. $23 \mathrm{pp}$.

Krishnaswami, S., M.S. Jolly and G. Subbarao. 1964. Diallel analysis of quantitative characters in multivoltine races of silkworm. Indian J. Genet. 24(3): 213-222.

Rahman, S.M. 1983. Technology of mulberry silkworm rearing suitable for the climatic condition in Bangladesh. Reshom. 1: 71-79.

Rahman, M.S. 1984. Studies on the genetic improvement of eri silkworm, Philosamia ricini. Boisd. of Bangladesh. Ph. D. thesis. Department of Zoology, Rajshahi University. 419 pp.

Rahman, S.M. 1994. Filament length inheritance in a six-parent diallel cross in the silkworm, Bombyx mori L. Bangladesh J. Zool. 22(2): 209-215.

Rahman, S.M. and S. Jahan. 2001. Gene action on cocoon size in silkworm, Bombyx mori L. (Lepidoptera: Bombycidae). Univ. j. zool. Rajshahi Univ. 20: 67-70.

Rahman, S.M., I.A. Ali and H.A. Rashid. 2004. Inheritance of fecundity and fertility in silkworm, Bombyx mori L. from all possible crosses between a set of parental lines. Univ. j. zool. Rajshahi Univ. 23: 69-72.

Reza, A.M.S. and S.M. Rahman 2005. Genetic parameters of some yield and yield contributing traits in silkworm, Bombyx mori L. Univ. j. zool. Rajshahi Univ. 22(2): 209-215.

Sarker, A., N.K. Das and B.C. Das. 1991. A diallel cross analysis of the cocoon weight in the silkworm, Bombyx mori L. Sericologia. 31(2): 301-306.

Satenahalli, S.B., R. Govindan and J.V. Goud. 1989. Genetic analysis of some quantitative traits by diallel cross in silkworm, Bombyx mori L. Sericologia. 29(3): 333-342.

Sengupta, K., R.K. Datta and S.N. Biswas. 1974. Effect of multiple crossing on the population pattern of the progeny in silkworm. Indian J. genet. 34A (Sabrao Proc): 241-248.

Shamsuddin, A.K.M. and M.A. Antoun 1986. Nature of gene action controlling yield and yield components in spring wheat. Bangladesh J. Agri. 11(3): 1-11.

Zhao, Y., K. Chen and S. HE. 2007. Key principles for breeding spring and autumn using silkworm varieties from our experience of breeding 873×874. Caspian J. Env. Sci. 5(1): 57-61.

(Revised manuscript received on 4.7.2012) 